\title{
Morphological Changes in the Smooth Muscle Cells of the Mouse Lower Oviduct during Pregnancy and Post-partum*
}

\author{
Maria-Simonetta Faussone-Pellegrini ${ }^{1}$, Patrizia Matini ${ }^{1}$ and Gastone Bani ${ }^{2}$ \\ Departments of Human Anatomy and Histology ${ }^{1}$, Section of Histology, and Animal Biology and Genetics ${ }^{2}$, University of \\ Florence, Italy
}

Received May 24, 1994; revised December 26, 1994

\begin{abstract}
Summary. The muscle coat of the lower region of the mouse oviduct undergoes morphological changes during pregnancy and post-partum. Ultrastructural examination and morphometrical findings show that, during pregnancy, the smooth muscle cells undergo a significant increase in both the number of mitochondria and caveolae and in the extension of the rough endoplasmic reticulum and Golgi apparatus, suggesting an enhancement of metabolic activities, especially protein synthesis. Within two days after delivery, the number of mitochondria and caveolae is similar to that of non-pregnant mice, whereas the extension of the rough endoplasmic reticulum and Golgi apparatus further increases significantly. The cytological signs of enhanced protein synthesis in the smooth muscle cells of the lower oviduct during pregnancy and, especially, in the post-partum period are probably related to a remodelling of the intercellular connective tissue matrix.
\end{abstract}

Previous ultrastructural studies on the mouse oviduct have demonstrated that the smooth muscle cells undergo substantial modifications during the various phases of the estrus cycle (FAUSSONE-PELLEGRINI and BANI, 1990), and that the upper oviductal region, including the infundibulum and ampulla, markedly changes during pregnancy and post-partum (FAUSSONE-PELLEGRINI et al., 1991), as compared with cycling mice.

It has also been shown that the muscle coat of the upper region of the mouse oviduct exhibits architectural and cytological features different from the lower region, which extends from the ampullary-isthmic to the utero-tubal junctions and has morphological features similar to those of the myometrium (FAUSSONEPELLEGRINI and BANI, 1990; VizZA et al., 1991; MUgLIA et al., 1991). These regional differences in smooth muscle cell cytology between upper and lower ovi- ducts in cycling mice are obviously related to the different contractile activities involved, respectively, in the fertilization and transport of the egg towards the uterus (BOLING and BLANDAU, 1971; HAFEZ, 1973; SAMUELSON and SJOSTRAND, 1986).

The characteristics of the morphological changes observed in the upper region of the mouse oviduct during pregnancy and post-partum were different from either those observed at the same level during the estrus cycle (FAUSSONE-PELLEGRINI and BANI, 1990) or those occurring in the myometrium during pregnancy and post-partum (CSAPO and CORNER, 1953; LAGUENS and LAGRUTTA, 1964; CSAPO et al., 1965; REYNOLDS, 1965; DE MATTOS et al., 1967; DesSOUKY, 1968; Kelly and Verhage, 1985; ThILANDER and RODRIGUEZ-MARTINEZ, 1989a, b, 1990).

The aim of this study is to investigate ultrastructurally and morphometrically whether changes also occur in the lower region of the mouse oviduct during pregnancy and post-partum and, if so, to compare them with those observed in the upper portion of the oviduct.

\section{MATERIALS AND METHODS}

\section{Animals}

Twenty-four adult virgin albino mice of the Swiss strain, weighing approximately $30 \mathrm{~g}$, were used. All were in early estrus. The phase of the estrus cycle was determined by a Papanicolau test on vaginal smears in the afternoon of the day before mating. Each female was left together with a male overnight. Twenty mice underwent fertilization, the remaining four being used as non-pregnant controls. The pregnant mice

\footnotetext{
*This work was supported by grants from the MURST, Rome, Italy.
} 
were divided into five groups. Three groups of four animals each were sacrificed one, two or three weeks after mating. Two groups were sacrificed the first day and the second day after delivery. The mice were killed by prolonged ethyl-ether anaesthesia. After being laparatomized their oviducts, attached to their respective uterine horns, were removed. Under a dissection microscope, the isthmus and the juxta-uterine portion of the oviduct were resected from the uterine horn and processed for electron microscopy examination.

\section{Electron microscopy}

Tissue fragments were fixed in $4 \%$ glutaraldehyde in $0.1 \mathrm{M}$ cacodylate buffer, $\mathrm{pH} 7.4$, postfixed in $1 \% \mathrm{OsO}_{4}$ in $0.1 \mathrm{M}$ phosphate buffer, $\mathrm{pH}$ 7.4, dehydrated in graded acetone series, and embedded in Epon 812 using flat moulds. Ultrathin sections were stained with uranyl acetate and alkaline bismuth subnitrate and examined under a Siemens Elmiskop 102 electron microscope at $80 \mathrm{kV}$.

\section{Morphometry}

The morphometrical analysis was performed on 12 different electron micrographs of smooth muscle cells, 6 from the circular and 6 from the longitudinal muscle layer, either transversely or longitudinally sectioned. These were chosen at random from each experimental group ( 3 for each mouse) and at a final magnification of $\times 35,000$.

The volume density of mitochondria, or Golgi apparatus, or rough endoplasmic reticulum in the smooth muscle cells $(\mathrm{V} / \mathrm{V})$ was evaluated by point counting with a double square test lattice after Merz (WEIBEL, 1979), with a distance of test points $d_{1}=1 \mathrm{~cm}$ for small points and $d_{2}=2 \mathrm{~cm}$ for large points. Small points $(p)$ were used to measure mitochondria and rough endoplasmic reticulum, large points $(\mathrm{P})$ for the Golgi apparatus and for the cytoplasm. The volume density was computed by the following equations: for Golgi apparatus: $\mathrm{V}_{\mathrm{G}} / \mathrm{Vcell}=\mathrm{P}_{\mathrm{G}} /$ Pcell; for mitochondria: $\mathrm{Vm} / \mathrm{Vcell}=\mathrm{pm} /(4 \cdot$ Pcell $)$; for rough endoplasmic reticulum: $\mathrm{Vr} / \mathrm{Vcell}=\mathrm{pr} /(4 \cdot \mathrm{Pcell})$.

The boundary length of the plasma membrane (B) was computed by intersection (I) counting with a curvilinear isotropic test lattice after Merz (WEIBEL, 1979) and applying the equation $\mathrm{B}=\mathrm{I} \cdot \mathrm{d} / \mathrm{M}: \mathrm{d}=1.84$ $\mathrm{cm}$ being the distance between test lines, and $\mathrm{M}$ being the magnification of photomicrographs.

\section{Statistical analysis}

The volume density of mitochondria, Golgi apparatus and rough endoplasmic reticulum and the number of profiles of caveolae $/ \mathrm{mm}$ cell boundary in the smooth muscle cells of circular and longitudinal muscle layers of the oviduct in estrus, pregnancy and postpartum were checked for homogeneity of variance by Bartlett's test. Since no significant inhomogeneity was found (the value of the test was, in each case, lower than that necessary to exclude homogeneity with $\mathrm{p}<0.05$ ), data were further subjected to a split ANOVA test, with two tails, assuming as error variance that stemming from individual differences. Probability levels that differences were due to chance, less than $5 \%(\mathrm{p}<0.05), 1 \%(\mathrm{p}<0.01)$ or $0.1 \%(\mathrm{p}<$ 0.001 ), were recorded and accepted as significant. Mean values and their standard deviations are presented in Table 1.

There was no significant difference between muscle layers (circular vs. longitudinal), whereas significant differences were found between experimental conditions. Differences among experimental conditions were tested pooling together, for each parameter and each experimental condition, the values for the circular layer and those for the longitudinal layer. Then, the values for each experimental condition were compared with those of each other experimental condition with Student's $t$ test. All tests were two tails. Probability levels that differences were due to chance, or less than $5 \%$, were registered and accepted as significant.

\section{RESULTS}

Visual examination during pregnancy showed the smooth muscle cells of both circular and longitudinal muscle layers appearing considerably enlarged, as compared with their counterparts in estrus (Figs. 13). Moreover, the number of mitochondria and caveolae was increased and the rough endoplasmic reticulum and Golgi apparatus appeared more extended (Figs. 2-6), whereas no appreciable change occurred in the extension of smooth endoplasmic reticulum.

Morphometrical analysis (Table 1) revealed that, from the second week to the end of pregnancy, there was a significant increase, as compared with controls, in the volume density of mitochondria and in the extension of the rough endoplasmic reticulum and Golgi apparatus. The number of caveolae per unit of the plasma membrane length rose significantly at the termination of pregnancy (Figs. 3A, B, 6), whereas no appreciable increase was found in the earlier stages of pregnancy (Fig. 2). No significant difference between circular and longitudinal muscle layers was found (Table 1).

Cells with the features of differentiating smooth 

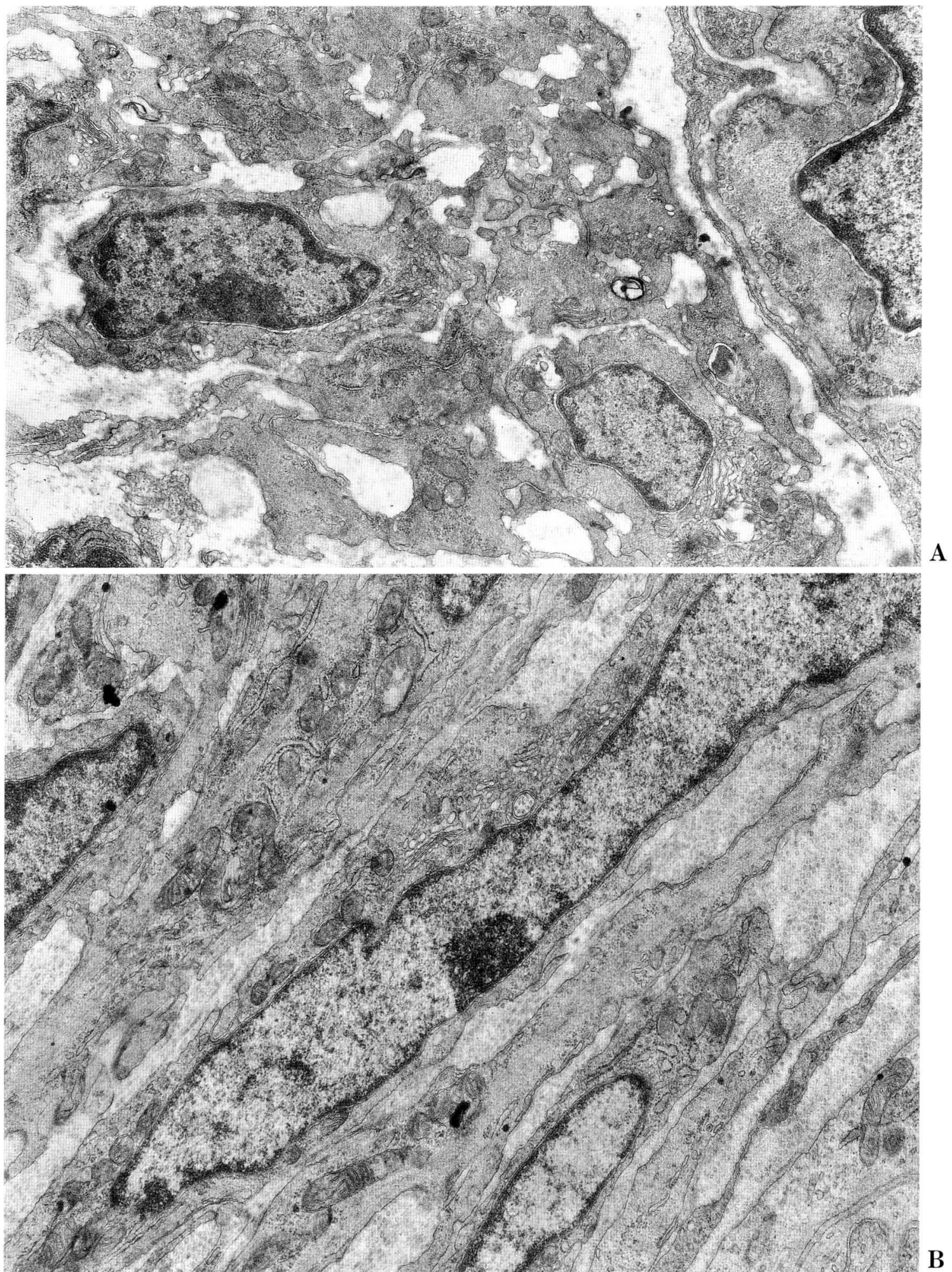

Fig. 1. Muscle coat of the mouse lower tuba during the estrus phase. Smooth muscle cells of the circular (A) and longitudinal (B) muscle layers. The rough endoplasmic reticulum and Golgi apparatus occupy wide cytoplasmic areas. A: $\times 16,000, \mathrm{~B}: \times 17,500$ 


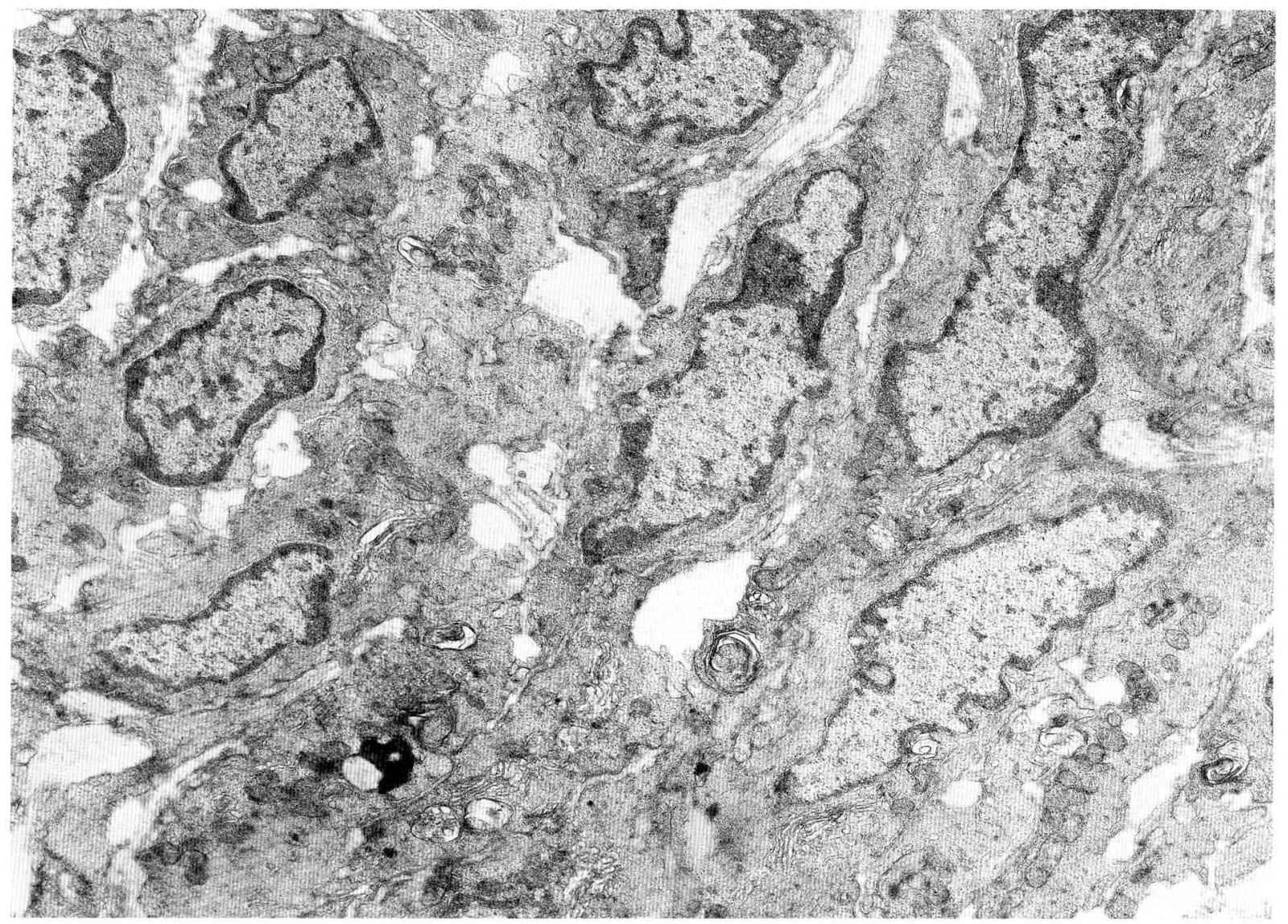

Fig. 2. Muscle coat of the mouse lower tuba. Day 7 of pregnancy. On the right side is the circular muscle layer, and on the left side, the longitudinal one. All smooth muscle cells have large clusters of mitochondria and a wide Golgi apparatus. $\times 12,500$

Table 1. Volume densities $(\mathrm{V} / \mathrm{V})$ of mitochondria, Golgi apparatus and rough endoplasmic reticulum (RER) and numbers (No.) of the profiles of caveolae/ $\mu \mathrm{m}$ cell boundary in the smooth muscle cells of circular (CL) and longitudinal (LL) muscle layers of the mouse oviduct in estrus, pregnancy and post-partum.

\begin{tabular}{|c|c|c|c|c|c|c|c|c|}
\hline & \multicolumn{2}{|c|}{$\mathrm{V} / \mathrm{V}$ of Mitochondria } & \multicolumn{2}{|c|}{$\mathrm{V} / \mathrm{V}$ of Golgi apparatus } & \multicolumn{2}{|c|}{$\mathrm{V} / \mathrm{V}$ of $\mathrm{RER}$} & \multicolumn{2}{|c|}{ No. of Caveolae $/ \mu \mathrm{m}$} \\
\hline & $\mathrm{CL}$ & LL & $\mathrm{CL}$ & LL & $\mathrm{CL}$ & LL & $\mathrm{CL}$ & LL \\
\hline Estrus & $\begin{array}{l}0.1370^{\mathrm{a}} \\
( \pm 0.0544)\end{array}$ & $\begin{array}{l}0.1172^{\mathrm{a}^{\prime}} \\
( \pm 0.0268)\end{array}$ & $\begin{array}{l}0.0381^{\mathrm{a}} \\
( \pm 0.0277)\end{array}$ & $\begin{array}{l}0.0392^{\mathrm{a}^{\prime}} \\
( \pm 0.0298)\end{array}$ & $\begin{array}{l}0.0389^{\mathrm{a}} \\
( \pm 0.0204)\end{array}$ & $\begin{array}{l}0.0409^{a^{\prime}} \\
( \pm 0.0272)\end{array}$ & $\begin{array}{l}0.6210^{\mathrm{a}} \\
( \pm 0.1915)\end{array}$ & $\begin{array}{l}0.5157^{\mathrm{a}^{\prime}} \\
( \pm 0.0779)\end{array}$ \\
\hline $\begin{array}{l}12-18 \text { days of } \\
\text { pregnancy }\end{array}$ & $\begin{array}{l}0.1387^{\mathrm{b}} \\
( \pm 0.0291)\end{array}$ & $\begin{array}{l}0.1454^{\mathrm{b}^{\prime}} \\
( \pm 0.0268)\end{array}$ & $\begin{array}{l}0.1035^{\mathrm{b}} \\
( \pm 0.0509)\end{array}$ & $\begin{array}{l}0.1073^{\mathrm{b} \prime} \\
( \pm 0.0658)\end{array}$ & $\begin{array}{l}0.1003 \\
( \pm 0.0697)\end{array}$ & $\begin{array}{l}0.0972 \\
( \pm 0.0640)\end{array}$ & $\begin{array}{l}0.8487^{\mathrm{b}} \\
( \pm 0.3878)\end{array}$ & $\begin{array}{l}0.8889^{\mathrm{b} \prime} \\
( \pm 0.3315)\end{array}$ \\
\hline $\begin{array}{l}\text { Pregnancy at full } \\
\text { term }\end{array}$ & $\begin{array}{l}0.1570^{c} \\
( \pm 0.0359)\end{array}$ & $\begin{array}{l}0.1335^{c^{\prime}} \\
( \pm 0.0268)\end{array}$ & $\begin{array}{l}0.1272^{c} \\
( \pm 0.0227)\end{array}$ & $\begin{array}{l}0.1201^{c \prime} \\
( \pm 0.0910)\end{array}$ & $\begin{array}{l}0.1137^{c} \\
( \pm 0.0357)\end{array}$ & $\begin{array}{l}0.1209^{c} \\
( \pm 0.0337)\end{array}$ & $\begin{array}{l}1.7464^{\mathrm{c}} \\
( \pm 0.7641)\end{array}$ & $\begin{array}{l}1.8225^{\mathrm{c}^{\prime}} \\
( \pm 0.2528)\end{array}$ \\
\hline $12-24 \mathrm{~h}$ post-partum & $\begin{array}{l}0.1039 \\
( \pm 0.0537)\end{array}$ & $\begin{array}{l}0.1110 \\
( \pm 0.0627)\end{array}$ & $\begin{array}{l}0.1378^{\mathrm{d}} \\
( \pm 0.0277)\end{array}$ & $\begin{array}{l}0.1385^{\mathrm{d}^{\prime}} \\
( \pm 0.0210)\end{array}$ & $\begin{array}{l}0.1223^{\mathrm{d}} \\
( \pm 0.0171)\end{array}$ & $\begin{array}{l}0.1255^{\mathrm{d}^{\prime}} \\
( \pm 0.0188)\end{array}$ & $\begin{array}{l}0.6288^{\mathrm{d}} \\
( \pm 0.3515)\end{array}$ & $\begin{array}{l}0.8249^{\mathrm{d}^{\prime}} \\
( \pm 0.6146)\end{array}$ \\
\hline 2-3 days post-partum & $\begin{array}{l}0.0730^{\mathrm{e}} \\
( \pm 0.0353)\end{array}$ & $\begin{array}{l}0.0914^{\mathrm{e}^{\prime}} \\
( \pm 0.0347)\end{array}$ & $\begin{array}{l}0.0760^{\mathrm{e}} \\
( \pm 0.0622)\end{array}$ & $\begin{array}{l}0.0755^{\mathrm{e}^{\prime}} \\
( \pm 0.0504)\end{array}$ & $\begin{array}{l}0.0513^{\mathrm{e}} \\
( \pm 0.0298)\end{array}$ & $\begin{array}{l}0.0470^{e^{\prime}} \\
( \pm 0.0299)\end{array}$ & $\begin{array}{l}1.0034^{\mathrm{e}} \\
( \pm 0.1840)\end{array}$ & $\begin{array}{l}1.0906^{\mathrm{e}} \\
( \pm 0.3108)\end{array}$ \\
\hline
\end{tabular}

No significant difference between layers (CL vs. LL) was found. Therefore, the values for the circular layer and those for the longitudinal layer were pooled together for each parameter and each experimental condition. Values in the table are expressed as mean \pm standard deviation. In all cases, the number of sample units was 6 . Significance levels were as follows.-Mitochondria: (a, a'), (b, b'), (c, c $\left.c^{\prime}\right)$ vs, $\left(e, e^{\prime}\right): p<0.01$; Golgi: (a, a') vs (b, b'): p < 0.01; (c, c'), (d, d')

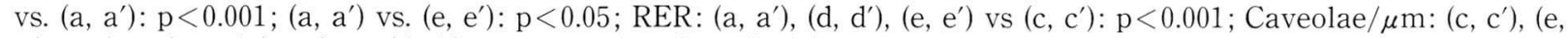
$\left.\mathrm{e}^{\prime}\right)$ vs. $\left(\mathrm{a}, \mathrm{a}^{\prime}\right)$, and $\left(\mathrm{c}, \mathrm{c}^{\prime}\right)$ vs. $\left(\mathrm{d}, \mathrm{d}^{\prime}\right): \mathrm{p}<0.001$; (a, $\left.\mathrm{a}^{\prime}\right)$ vs. $\left(\mathrm{b}, \mathrm{b}^{\prime}\right): \mathrm{p}<0.01$; (b, $\left.\mathrm{b}^{\prime}\right)$ vs. $\left(\mathrm{c}, \mathrm{c}^{\prime}\right): \mathrm{p}<0.05$. 


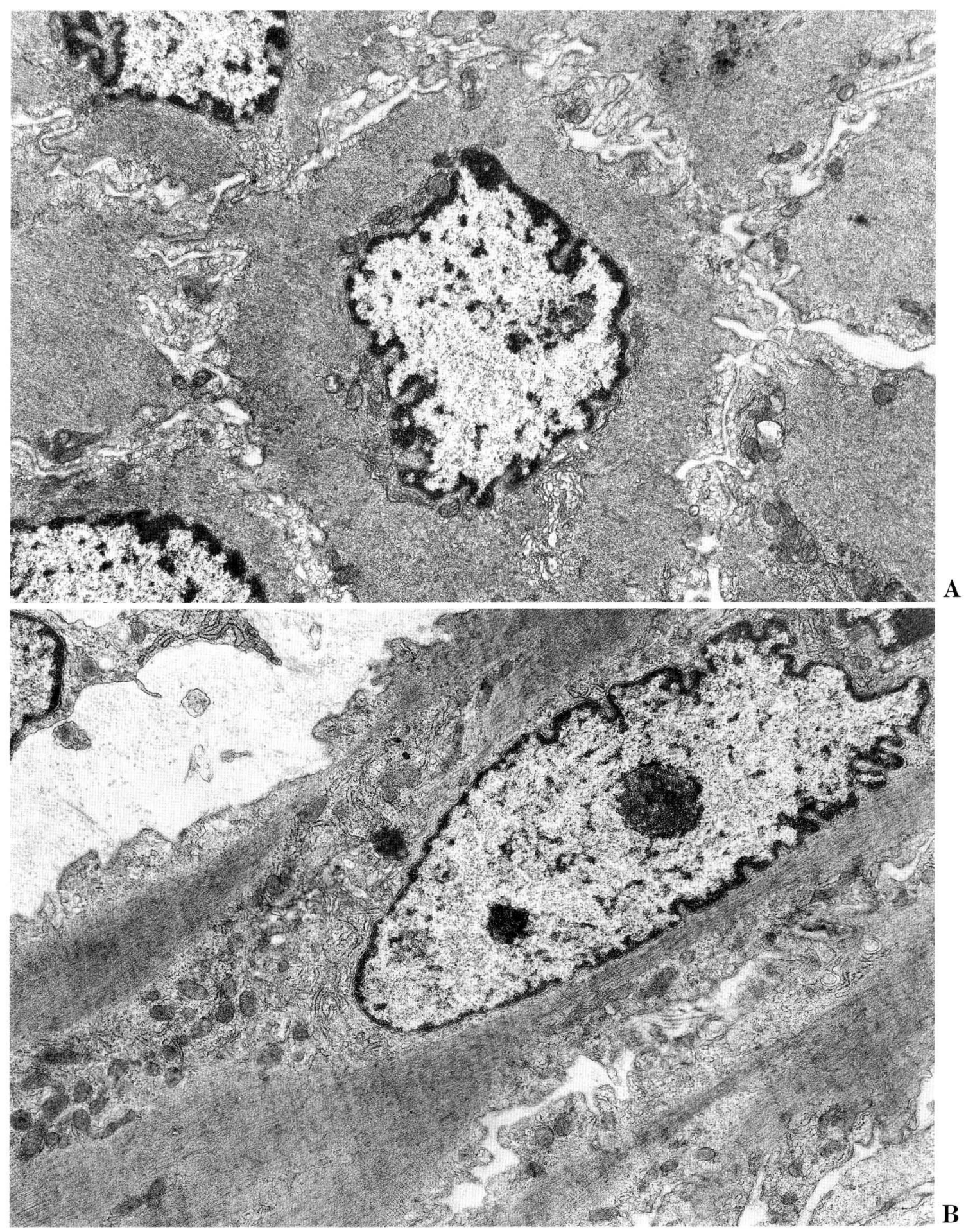

Fig. 3. Muscle coat of the mouse lower tuba. Twelve hours before delivery. Smooth muscle cells of the circular (A) and longitudinal (B) muscle layer rich in caveolae and with an extended rough endoplasmic reticulum and Golgi apparatus are seen. $\times 12,500$ 


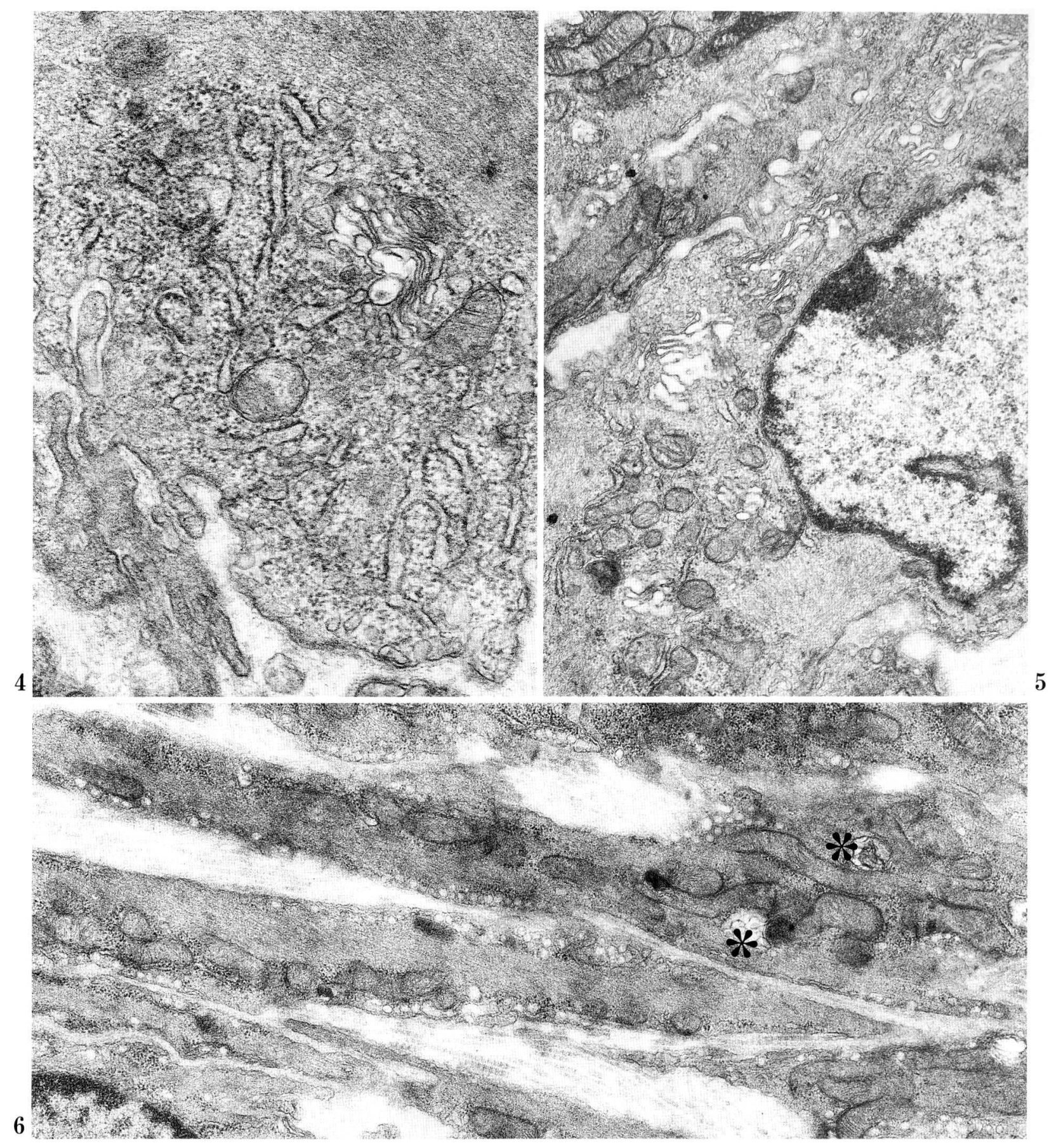

Fig. 4. Twelve hours before delivery. Cisternae of the rough endoplasmic reticulum grouped at the cell periphery near the sarcolemma. $\times 37,500$

Fig. 5. Day 15 of pregnancy. Most of the perinuclear cytoplasm of smooth muscle cells is occupied by an extremely wide Golgi apparatus. $\times 20,000$

Fig. 6. Twelve hours before delivery. Caveolae open over the entire surface of the smooth muscle cells. Asterisks: myelinic figures. $\times 12,500$ 


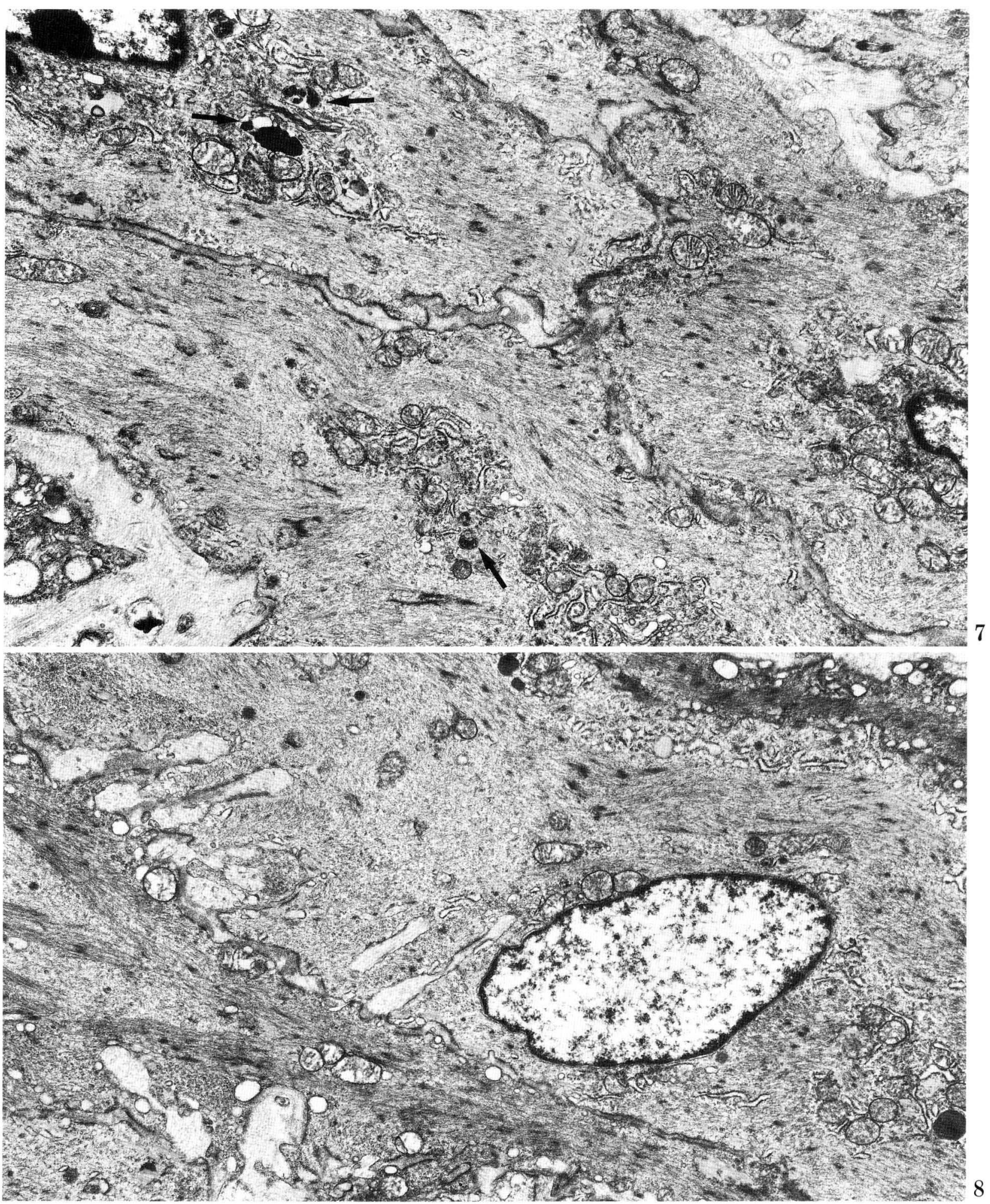

Fig. 7. Twelve hours after delivery. Hypertrophic smooth muscle cells, showing wide Golgi apparatus and rough endoplasmic reticulum. Arrows indicate pleomorphic lysosomes. $\times 10,000$

Fig. 8. Twenty-four hours after delivery. Deep finger-like invaginations of the plasma membrane containing collagen fibers are present all along the smooth muscle cell contour. $\times 10,000$ 
muscle cells (myoblasts) and gap junctions between smooth muscle cells were never observed during pregnancy nor before delivery. From the second week of pregnancy, collagen fibers with typical cross banding and a diameter ranging from 30 to $60 \mathrm{~nm}$ were numerous (Figs. 2, 3A, B).

During post-partum, some of the changes which occurred during pregnancy regressed completely, while others became even more marked immediately after delivery (Figs. 7,8 ) to then regress. In particular, early in post-partum, the volume density of mitochondria and the number of caveolae decreased significantly, whereas the rough endoplasmic reticulum and Golgi apparatus increased even more (Table 1), becoming larger than at pregnancy at full term (Figs. $7,8)$. Another peculiar finding of the post-partum period was the presence of numerous pleomorphic lysosomes scattered throughout the cytoplasm either singly or in small clusters. Some of them resembled myelin-like figures, and others primary lysosomes or autophagic vacuoles containing whole mitochondria or their remnants (Figs. 7, 8).

The first day after delivery, some infolds of the smooth muscle cell plasma membrane containing small bundles of collagen fibers appeared (Fig. 8). One day later, the intercellular matrix displayed the same features as in estrus.

\section{DISCUSSION}

The results of the current study show that the smooth muscle cells of both the circular and longitudinal muscle layers of the lower region of the mouse oviduct during pregnancy and the post-partum period become hyperthrophic, undergoing marked cytological changes consistent with enhanced metabolic activity and protein synthesis.

During pregnancy, in fact, the extension of the rough endoplasmic reticulum and Golgi apparatus of the smooth muscle cells increases significantly, similar to the myometrial cells which in this period are thought to be engaged in the formation of collagen and elastic fibers of the uterine stroma (LAGUENS and LAGRUTTA, 1964; Dessouky, 1968; Kelly and VerHAGE, 1985). This may imply that, similar to myometrium, the stroma of the lower oviduct undergoes a remodelling during pregnancy, although without showing (OTTANI et al., 1992) the modifications in the collagen fiber shape and size which were noted during this period at the upper oviduct (FAUSSONE-PELLEGRINI et al., 1991).

Our previous studies on the upper oviduct showed that during pregnancy the smooth muscle cells become enriched in mitochondria, caveolae and smooth endoplasmic reticulum (FAUSSONE-PELLEGRINI et al., 1991). The smooth muscle cells of the lower oviduct also become enriched in caveolae and mitochondria but do not show pregnancy-induced changes in the extension of the smooth endoplasmic reticulum. This differing response of the smooth muscle cells in these two parts of the oviduct is probably related to regionspecific differences in their contractile activities, these being spontaneous (myogenic) in the upper oviduct and controlled by the former (peristaltic) in the lower oviduct.

Smooth muscle cell hyperplasia has been found in the lower oviduct during proestrus (FAUSSONEPELLEGRINI and BANI, 1990) and probably still occurs in the earlier stages of pregnancy. Later on, during the stages here studied, cells with the features of differentiating smooth muscle cells are no longer observed, similar to what has also been noted for the upper oviduct (FAUSSONE-PELLEGRINI et al., 1991).

Furthermore, unlike the uterine smooth muscle cells which develop gap junctions just before and during delivery (GARFIELD et al., 1978; THILANDER and RODRIGUEZ-MARTINEZ, 1990), all oviductal smooth muscle cells have been found lacking these. This suggests that gap junctions are not needed in this region for the propagation of the contractile waves.

The numerous lysosomes and autophagic bodies found in the smooth muscle cells after delivery are probably engaged in the destruction of cell components no longer needed, as also observed in the upper oviduct during pregnancy and in metestrus (FAUSSONE-PELLEGRINI and BANI, 1990; FAUSSONE-PELLEGRINI et al., 1991).

The rough endoplasmic reticulum and Golgi apparatus greatly enlarge immediately after delivery, becoming, only two days afterwards, similar to estrus. This finding strongly suggests that after delivery smooth muscle cells are still engaged in active protein synthesis, probably needed in the remodelling of the interstitial connective tissue, as also occurs in the same period in the endometrium (ZORN et al., 1986). The role of lysosomes in the destruction of the intercellular matrix cannot be ruled out, although clearcut images of internalization and intracellular degradation of connective tissue components could not be found in this study.

In conclusion, during pregnancy the muscle coat of the entire oviduct undergoes morphological changes. Some of these are consistent with an increased contractile activity (especially at the upper oviduct), and others with an increased protein synthesis (especially at the lower oviduct). Moreover, during the post-partum period, the protein synthesis likely serving for a remodelling of the intercellular connective tissue matrix seems further enhanced in the lower oviduct. 


\section{REFERENCES}

Boling, J. L. and R. J. BlandaU: Egg transport through the ampulla of oviduct of rabbits under various experimental conditions. Biol. Reproduct. 4: 174-184 (1971).

CsaPo, A. I. and G. W. Corner: The effect of estrogen on the isometric tension of rabbit uterine strips. Science 117: 162-164 (1953).

Csapo, A. I., T. Erdos, C. E. R. DE Mattos, E. Graness and C. Moscowitz: Stretch-induced uterine growth, protein synthesis and function. Nature 207: 1378-1379 (1965).

De Mattos, C. E. R., R. L. Kempson, T. Erdos and A. CsAPo: Stretch-induced myometrial hypertrophy. Fertil. Steril. 18: 545-556 (1967).

Dessouky, D. A.: Electron microscopic studies of the myometrium of the guinea pig. The smooth muscle cell of the myometrium before and during pregnancy. Amer. J. Obstet. Gynecol. 100: 30-41 (1968).

Faussone-Pellegrini, M. S. and G. Bani: The muscle coat morphology of the mouse oviduct during estrous cycle. Arch. Histol. Cytol. 53: 167-178 (1990).

Faussone-Pellegrini, M. S., G. Bani and S. Bianchi: Ultrastructural modifications of the muscle coat of the ampulla and infundibulum of the mouse oviduct during pregnancy and postpartum. Arch. Histol. Cytol. 54: 289298 (1991).

Garfield, R. E., S. M. Sims, M. S. Kannan and E. E. DANIEL: Possible role of gap junctions in activation of myometrium during parturition. Amer. J. Physiol. 235: C168-C179 (1978).

HaFEz, E. S. E.: Endocrine control of the structure and function of the mammalian oviduct. In: (ed. by). R. O. GREEP and E. B. AsTwOOD: Handbook of physiology. Sect. 7, Vol. II. Female reproductive system, Part 2. American Physiological Society, Washington DC, 1973 (p. 97-122).

Kelly, R. E. and H. G. VerhaGe: Structural changes in the contractile apparatus of the myometrium during estrous and pregnancy. J. Submicrosc. Cytol. 7: 1-10 (1985).

LAguens, R. and J. LAGRUTta: Fine structure of human uterine muscle in pregnancy. Amer. J. Obstet. Gynecol. 89: 1040-1048 (1964).

Muglia, U., E. Vizza, S. Correr, G. Germana and P. M. MoтTA: Architecture of the myosalpinx isthmus in the guinea pig by means of scanning electron microscopy. Acta Anat. 142: 171-173 (1991).
Ottani, V., M. S. Faussone-Pellegrini, M. Raspanti, V. De Pasquale, C. Zucchini and A. Ruggeri: Ultrastructural modifications of uterine extracellular matrix during pregnancy. Eur. J. Histochem. 36 (Suppl.): 19-20 (1992).

ReYnolds, S. R. M.: Physiology of the uterus. Hafner Publishing, New York, 1965.

Samuelson, U. E. and N. D. SJostrand: Myogenic and neurogenic control of electrical and mechanical activity in human oviductal smooth muscle. Acta Physiol. Scand. 126: 355-363 (1986).

Thilander, G. and H. Rodriguez-Martinez: Fine structure of the porcine myometrium during the oestrous cycle. Acta Anat. 134: 160-170 (1989a).

- Ultrastructure of the porcine myometrium during pregnancy. Acta Anat. 136: 99-106 (1989b).

- : Morphology of the porcine myometrium during parturition. Acta Anat. 137: 77-85 (1990). Vizza, E., U. Muglia, G. Macchiarelli, L. Baschieri, N. Pasetta and P. M. Motta: Three-dimensional architecture of the human myosalpinx isthmus. Scanning electron microscope after $\mathrm{NaOH}$ digestion and ultrasonic microdissection. Cell Tiss. Res. 266: 219-221 (1991).

WeibeL, E. R.: Stereological methods. Vol. I. Pratical methods for biological morphometry. Academic Press, London, 1979.

Zorn, T. M. T., E. M. A. F. Bevilacqua and P. A. Abrahamson: Collagen remodelling during decidualization in the mouse. Cell Tiss. Res. 244: 443-448 (1986).

Prof. Gastone BANI

Dipartimento di Biologia animale e Genetica Università degli Studi di Firenze

Via Romana, 17

50125 Florence, Italy 